\title{
Soft and Hard: Intimations Insinuations Implications
}

By Rod Stoneman

Fall 2006 Issue of KINEMA

\section{SOFT AND HARD: INTIMATIONS INSINUATIONS IMPLICATIONS}

At a time when television was extending its bravery and its boundaries, when it offered creative space for the world's film-makers, when a cinema of ideas was still possible...

In 1985, working as Deputy Commissioning Editor in the Independent Film and Video department of Channel 4, I took on both the programming of a Godard season and the production of a new piece of specially commissioned work from Jean-Luc Godard and Anne-Marie Miéville originally entitled A Gentle Conversation on Rough Subjects, which became A Soft Conversation between Two Friends on a Hard Subject (1985) or Soft and Hard for short. Channel 4 was an extraordinary and exciting laboratory at this time, "rebuilding the ship at sea" as a new and radical version of public service television; a publisher broadcaster with a remit to "innovate and experiment in the form and content of programmes." The Independent Film and Video department had contributed significantly to these aims through commissioning and buying a range of political and personal documentary, experimental, access and community programmes, low budget fiction and third world cinema.

After Soft and Hard, I visited Godard and Miéville on several further occasions in Rolle, buying for the channel Grandeur et décadence d'un petit commerce de cinéma (1986), the first two chapters of Histoire(s) du cinéma (1989), and Miéville's Mon cher sujet (1989).

The structure and focus of the final version of Soft and Hard are very different to those originally envisaged. Godard turned up in London in the autumn of 1984 and the notion of making a new piece to lead a Channel 4 season of his recent work had been agreed in principle in Café Valerie in Old Compton Street. It was in fact originally to be a film called British Images, to complement British Sounds that had been made for London Weekend Television in 1969 but quickly shelved when completed. ${ }^{(1)}$ The company structure of The Other Cinema was to be utilised for the new production; as British distributor they had previously sold Channel 4 a substantial section of Godard's work from Le gai savoir (1968) through the films with the Dziga Vertov Group and Jean-Pierre Gorin to Numéro deux (1975) with Anne-Marie Miéville. Many of these formed the basis of the season: Le gai savoir, Pravda (1969), Numéro deux, and Passion (1982) were shown in the "Eleventh Hour" on Monday evenings, France tour détour deux enfants (1979) ran very late at night at the end of the schedule and One Plus One (1968), Tout va bien (1972) and Sauve qui peut (la vie), 1980) were screened in a world cinema slot. I edited a common title sequence to tie the season together and Colin MacCabe provided short introductions for the individual films. This season was of some cultural importance because it allowed, for the first time anywhere in the world, a television audience to watch a substantial section of Godard's work from the late 60s and 70s and included the first programme he had made specifically for television in over five years. Channel 4 also produced a booklet for educational usage.

Soft and Hard is an important film in the context of the development of Godard and Miéville's work together which addresses their creative process and its context. Constructed around an extensive dialogue between the two of them, it is filmed with a static camera. There is a lack of image intensity in the long conversational passage where multi-layered visual density recedes and I have a memory of Jean-Luc explaining, with a slightly apologetic tone, that they would have liked longer to work on the piece overall - but as delivery was driven by the urgent transmission deadline for Soft and Hard at the end of the television season we all had to fall in with that. Setting aside the starting point of its title - the double entendre and crucial delineation of "Hard" and "Soft" as terms normally deployed both in pornography and electronic technology - the film embarks on a poetic meditation on the intersection of their work as film-makers, jointly and separately, and their lives in the domestic sphere. Jean-Luc's voice-over begins the search for "the path to our language" with references to the passing meanings of the "outside" world, both imperatives and distractions: the momentous (daily massacres in Beirut) and the diverting (tennis). These references play alongside the limpid sounds of Beethoven's late quartet in A Minor opus 132, setting the poignant and intimate tone maintained throughout. 
Their conversation addresses two principal questions: the differences in their position and relation as filmmakers and then the context in which their work is made and shown in the contemporary audio visual domain. They discuss each other's demeanour and disposition with remarkable candour and contrast their relative feelings and confidence in facing the world. Anne-Marie talks with self-effacing hesitation: "There are times when I feel that whatever originality there is in me... is very fragile. And since film-making for me is not as powerful and unique as it is for you."

Several years before Godard had talked of the difficulties in equalising the working dynamic with Jean-Pierre Gorin: "In any relationship with me they have too much respect and too much admiration, which is ruinous. You can't have a normal relationship, you're constantly being put in an elevated position." (2) Here, a younger, less-experienced female film-maker is collaborating with an older male director of incomparable experience and status: although no reference is made to the familiar terms of gender politics in Soft and Hard, it is impossible not to see them as another dimension of this disparity.

They discuss her criticisms of a problem in one of his films - the love scenes with Nathalie Baye or Johnny Hallyday in Detective (1985). His comment "Star or unknown, it comes to the same thing" (about two performers who were a married couple at the time of shooting the film) dissolves the very dichotomy between documentary and fiction that, following Bazin, he has always questioned.

Her tentative uncertainty about the originality of her own work ("You're never in doubt that whatever you have to say is of interest" she says, whilst "I'm more frightened, full of doubts...")is sharpened in proximity to the robust ironic confidence of her partner whose name looms so large in the history of cinema: "While you, even in the midst of turmoils and crowds... you speak out, you do not hesitate to speak and be heard. You're never in doubt that whatever you have to say is of interest. Since it is interesting for you, it must be interesting to all. It must exist."

Their dialogue openly exposes the extreme ego vulnerability of the film-maker, or creative artist more generally, who has to stand in public in front of what they have made. At a certain level of experience perhaps external reception and critical review can become less relevant or less potentially wounding, but it is difficult to underestimate the susceptibility of the artist and the degree of exposure and jeopardy for a new film-maker. The self cannot be separated from the art, their body from the body of their work. Jean-Luc's response to the problems Anne-Marie is articulating is a constructive approach: disregard external issues, ignore the oppressive weight of status or the history of cinema more generally as extraneous. "If there's anything to respect it is that art is getting out of yourself, like making a child" and concentrate on making the new work, that "vain and yet sublime activity."

The second part of their dialogue talks of television as the usurper of historical cinema: there is a sense of loss and anger at the destruction of (a certain kind of) cinema and its pervasive replacement by a new organisation of images on television. In disparagement and denunciation they speak metaphorically of feeling like the French under German occupation; this preliminary polemic is an early version of the position developed and enunciated so powerfully in Histoire(s) du cinéma and subsequent films. ${ }^{(3)}$

Their critique of what has become the medium's predominant spectacular form is strengthened by interspersed images, banal and metonymic fragments of spurious advertisements and specious captions like "catastrophe" behind a newsreader which invoke what Saul Bellow dubbed the "moronic inferno" of contemporary television. Through this extended conversation, Godard and Miéville establish the televisual essay as a ludic space where a questioning mentality can play inventively; their calm and critical dialogue articulates a mode of discourse, a specific form of thought: profuse and metaphoric, honest and oblique. ${ }^{(4)}$ Aided with the lubrications of irony they circle the same preoccupations about image and text, cinema and the politics of being human - developing that "path to their own language" to question the way things are... Some of their assertions, such as those about projection / subject / subjugation may not be substantial or sustainable in any kind of traditional theoretical or academic context, but they do offer a brilliant and exemplary mode of thought, developing film as "a form that thinks"(5) which can counter the doxa of received ideas.

In early 1985 it became clear that British Images would not come to pass - $£ 24,000^{(6)}$ of the $£ 40,000$ licence fee had already been paid to Sonimage for this film and it should have been delivered in December 1984 - and we became concerned that the prospect of the new Godard-Miéville project, a crucial dimension of 
the season, was in jeopardy. The late Tony Kirkhope, a leading member of The Other Cinema collective adopted his executive producer's role with panache and we travelled to Rolle together late in May to discuss plans for a new programme where "Jean-Luc Godard and Anne-Marie Miéville would interview each other and discuss their previous film work," to be produced for $£ 30,000$ (the monies already paid plus a further $£ 6,000)$. A lot of fax correspondence and numerous phone conversations were necessary to take the project through in such a short space of time - basically two months from commissioning to completion as Channel 4 looked for delivery in July to subtitle and publicise the new programme. I went to Rolle again at the end of June to view the rough cut material and discuss the approach to sub-titling. The film was transmitted at $10.45 \mathrm{pm}$ on 12 August 1985.

My experience of the dynamics involved in commissioning this piece was harmonious and delightful, which was not always true of independent productions. On a personal level, Jean-Luc was always solicitous about my first son, who was born at that time. In fact he knew Adam had been born just a couple of days after a visit to Rolle and sent a warm note, and there was for me a certain poignancy in his kind concerns and the question he poses in Soft and Hard "Oh, So I'm making pictures instead of making children. Does that stop me being a human being?" Many years later I discovered that this line was adapted from a letter from Vincent Van Gogh to his brother Theo; even this seemingly most personal and intimate area of self-expression takes place through a quotation.

During the production process, the interface was generally with Jean-Luc rather than Anne-Marie and I was struck forcefully by the continuity between his imaginative and discursive work and other aspects of his life. With many other film-makers there was a change of gear and a pause as they moved from creative to financial business, but not with Godard whose imaginative, curious and witty sensibility moved with a immediate gentle irony across ideas, arrangements and deal-making without a break. One quickly noticed that he was, if not ego-less, relatively unconcerned with his status. Other famous film-makers might make an effort to be almost ordinary, but you inevitably noticed the effort - Jean-Luc had no concern with how he was being regarded at all. I have a strong memory of the occasion on which I had to take a taxi from Rolle all the way to Geneva airport and didn't have enough cash - Jean-Luc threw 200 Swiss Francs in notes on the table with an extraordinary gesture that indicated that the money might pass through him but it wasn't a preoccupation of his and all this without the slightest awkwardness.

As a diagram for the realisation of the project provided by Jean-Luc indicated, Soft and Hard was, like the world itself, made in almost seven days, with a rest on dimanche. But neither economic nor aesthetic value can be calculated in a linear fashion; a more relevant model may be the apocryphal tale of the Japanese potter who, when asked how long it took him to make a specific vase replied "thirty minutes and thirty years." The strange transactions involved in turning "money into light," as John Boorman has eloquently described the process of film production, are parodied in the comic shot of JLG picking at figures on his desk calculator while on the phone talking about King Lear (1987) "we must finalise the deal..." he says in English. In fact the diagram indicated a careful plan for the film and the way it was to be made; it served as a configuration of timed segments and a shooting schedule for achieving them, a shorthand semi-symmetrical structuring of the questions they are to address. The quoted material is to progress chronologically from silent film, to sound cinema, to colour cinema and finally television. Of course this proposal changed en route and the underlying structure is not explicit in the finished work, unlike the numbered sections of Vent d'est (1969) for example. The seriousness and precision of their approach was evident; we agreed on subtitling after a debate about the relative merits of dubbing for an Anglophone audience. Orna Kustow prepared draft sub-titles with rare exactitude and care and Godard and Miéville made meticulous amendments. ${ }^{(7)}$

To return to Soft and Hard these twenty years later is a shock - that such a programme could be made for a British television station, that such a season could be transmitted is simply inconceivable at the present time and indicates how far public service broadcasting has slipped backwards in the last two decades. Significantly Collages de France exists in the space of an art gallery. ${ }^{(8)}$ The very dissemblance and delusion of most television described by Miéville in Soft and Hard needs to be contested in its own sphere, with its own audience: "Television never shows things, yet it makes you think that it never stops showing them; and this is what showing things is and that there's no other way to show them..." 


\section{Notes}

1. Although British Sounds was not broadcast, two short extracts were incorporated into the "Aquarius" programme on 2 January 1970. This was a pre-recorded and heavily edited debate between an audience of workers, students and intellectuals around some of the issues raised by the film, including the question of whether it should be broadcast. See Jan Dawson, "Raising the Red Flag," Sight and Sound, vol. 39, no. 2, pp. 90-91.

2. Colin MacCabe, Godard: Images, Sounds, Politics (London: BFI, 1980), p 76.

3. Soft and Hard prefigures the form and method of Histoire(s)du cinéma, understanding cinema through images of cinema, as noted in Michael Temple and James S. Williams (eds.), The Cinema Alone (Amsterdam: Amsterdam University Press, 2000), p. 76.

4. Rod Stoneman, "Among Godard's Forms of Thought" Undercut 2, 1981; anthologised in Nina Danino and Michael Maziere (eds.), The Undercut Reader (London: Wallflower Press, 2002), pp. 200-203.

5. Godard's articulation in chapter 3A of Histoire(s) du cinéma, La Monnaie de l'absolu.

6. Editor's note: 1 GBP = approx. 1.9 USD (November 2006 exchange rate).

7. Some years later, Orna Kustow also worked on the first two episodes of Histoire(s) du cinéma, coping with the extraordinary density of sound and image tracks from superimposed and combined film extracts, multi-layered captions and voice-over by moving sub-titles around the frame. (Initial versions of chapters 1A and 1B were discussed in 1988, purchased in 1991 and transmitted on Channel 4 on 21 and 28 June 1993).

8. The Centre Pompidou continues to offer an alternative to dominant forms of film - Isaac Julien's exhibition in 2005 and Collages de France itself exemplify the process whereby many film-makers in Europe have been driven from the wider public sphere into the gallery.

\section{Author Information}

Rod STONEMAN is Director to Huston School of Film and Digital Media, National University of Ireland in Galway. He previously served as Chief Executive of the Irish Film Board and a deputy commissioning editor of independent film and video at Channel Four. He has made several independent programmes for television (including "Between Object and Image," "Ireland: The Silent Voices," and "Italy: The Image Business"), written for Screen, Sight and Sound, Framework, and Afterimage. 